\section{Shelf-life of Halal fresh and minced beef meat packaged under modified atmosphere}

\author{
Francesca Piras, ${ }^{1}$ Domenico Meloni, ${ }^{1}$ \\ Daniele Casti, ${ }^{1}$ Roberta Mazza, ${ }^{1}$ \\ Federica Fois, ', Giovanna Coppa, ${ }^{2}$ \\ Rina Mazzette ${ }^{1}$
}

'Dipartimento di Medicina Veterinaria,

Università di Sassari; ${ }^{2}$ Azienda di

trasformazione carni La Genuina Srl,

Ploaghe (SS), Italy

\section{Abstract}

The shelf-life of Halal fresh cut and minced beef meat, packaged under modified atmosphere (MAP) was evaluated. The microbial profile of the carcasses intended for cutting and mincing was investigated by detecting spoilage and pathogenic bacteria. Samples of diced meat (DM), marrowbones (MB), steaks (S) and minced meat (MM) were packaged in MAP $\left(66.0 \% \mathrm{O}_{2}, 25.0 \% \mathrm{CO}_{2}\right.$ and $\left.9.0 \% \mathrm{~N}_{2}\right)$ and stored at +2 and $+8^{\circ} \mathrm{C}$. At 0,7 and 14 days, gas composition of headspace was measured. Moreover, in all the samples colony count at $30^{\circ} \mathrm{C}$, Enterobacteriaceae, lactic acid bacteria (LAB) and Pseudomonas spp. were determined. The carcasses contamination was in compliance with the criteria fixed by EC Reg. 2073/2005. Gas composition of the headspace changed significantly during the storage, mainly at $+8^{\circ} \mathrm{C}$, where a significant decrease of $\mathrm{O}_{2}$ (until $0.1-0.6 \%$ ) and an increase of $\mathrm{CO}_{2}$ (until 81.0-89.0\%) were recorded. This could be related to the level of $\mathrm{LAB}$ and Pseudomonas spp. Less significant changes were observed at $+2^{\circ} \mathrm{C}$. At 7 days of storage colony count, mean values were higher than $>10^{7} \mathrm{CFU} / \mathrm{g}$ in the samples at $+8^{\circ} \mathrm{C}$, and also at 14 days at $+2^{\circ} \mathrm{C}$, presumably due to the high levels of Pseudomonas spp., that was dominant at the end of the test. Overall, the microbial mean counts were higher than those detected in similar products packaged under vacuum. In order to extend the shelf-life of the fresh meat and meat preparations, differentiated gas mixtures, and particularly a higher percentage of $\mathrm{CO}_{2}$, could be employed.

\section{Introduction}

Food choice reflects aspects of lifestyle, culture, religion, diet and health concerns (Nakyinsige et al., 2012). Islam dietary laws determine which foods are permitted (i.e. Halal) or forbidden (i.e. Haram). For Muslims, the dietary laws are binding and must be observed at all times (Simoons, 1994; Bonne and Verbeke, 2008). In the past, meat for Muslim consumption was sold fresh at easily recognisable joints, overwrapped for shortterm chilled storage. Today, the food chain has become longer and people's lifestyle, included those of people who follow religious dietary laws, have greatly changed.

To extend the shelf-life of fresh meat, meat preparations and meat products stored at refrigeration temperature (Nakyinsige et al., 2012), modified atmosphere packaging (MAP) is still one of the most widely used technologies. For fresh red meat a gas mixture with $80 \% \mathrm{O}_{2}$ and $20-30 \% \mathrm{CO}_{2}$ is commonly used (McMillin, 2008). The purpose of the high-oxygen content is to maintain the bright red oxymyoglobin colour of the meat, although aerobic chilled storage supports the growth of Gram-negative, aerobic rod-shaped bacteria, including Pseudomonas spp. and other spoilage organisms, that can reduce the shelflife and generate off-flavours (Esmer et al., 2011).

The aim of this study was to determine the shelf-life of halal fresh and minced beef meat packaged in MAP. The research was carried out in collaboration with a meat processing plant placed in Sardinia, with the view to supply a retail outlet of halal beef, sheep and goat meats. With this aim, we considered the contents of annex II of EC Regulation 2073/2005 (European Commission, 2005) regarding the studies that food business operator shall conduct, in order to guarantee the compliance with the food safety criteria throughout the shelf-life. In particular, we referred to the Technical Guidance Document on shelf-life laboratory durability and challenge studies for Listeria monocytogenes in ready-to-eat foods (European Community, 2008).

\section{Materials and Methods}

The study was carried out from October 2010 to July 2011. Samples obtained from two batches (L1 and L2) of beef meat, coming from 12 animals slaughtered with the religious Halal method in a slaughterhouse placed in Sardinia, were examined.

\section{Measurements at slaughterhouse}

Carcass $\mathrm{pH}$ and temperature recording were measured one hour after slaughtering, in $M$. longissimus dorsi between the $4^{\text {th }}$ and the $7^{\text {th }}$ rib, using a portable $\mathrm{pH}$-meter, equipped with a pH-electrode fixing and a temperature probe (Crison GLP21; Crison Instruments, Alella, Spain). As for microbial sampling of carcasses, each carcass was sampled after evisceration and before chilling by sponge, according to ISO
Correspondence: Francesca Piras, Dipartimento di Medicina Veterinaria, Università di Sassari, via Vienna 2,07100 Sassari, Italy.

Tel. +39.079.229447 - Fax: +39.079 .229458 .

E-mail: fpiras@uniss.it

Key words: Meat, Beef, ATM, Shelf-life, Halal.

Conflict of interests: the authors declare no potential conflict of interests.

Funding: this work was partially supported by Sardinian regional founds (R.L. n.7/2007).

Conference presentation: part of this paper was presented at the $22^{\text {nd }}$ AIVI National Congress, September 19-21, Turin, Italy.

Received for publication: 28 March 2013

Revision received: 4 June 2013.

Accepted for publication: 4 June 2013.

This work is licensed under a Creative Commons Attribution 3.0 License (by-nc 3.0).

(C) Copyright F. Piras et al., 2013

Licensee PAGEPress, Italy

Italian Journal of Food Safety 2013; 2:e37

doi:10.4081/ijfs.2013.e37

17604 (Reg. EC 2073/2005) (European Commission, 2005) at shoulder, brisket, rump and loin sites. All the sponge samples coming from carcasses were analysed for colony count at $30^{\circ} \mathrm{C}$ (ISO $4833: 2004$ ) (UNI, 2004b), Enterobacteriaceae (ISO 21528-2:2004) (UNI, 2004a), Verocytotoxin-producing E.coli (VTEC), (Mazzette et al., 2012), E. coli (IS0 16649:2001) (ISO, 2001), Salmonella spp. (IS0 6579/2002) (ISO, 2002), and Listeria monocytogenes (ISO 11290-1:1996 and 11290-2:1998) (ISO, 1996, 1998).

\section{Measurements at meat processing plant}

Carcass $\mathrm{pH}$ and temperature were measured $24 \mathrm{~h}$ after slaughtering, as previously described.

\section{Shelf-life studies}

After storage of the carcasses at $+2 \pm 2^{\circ} \mathrm{C}$ for 15 (L1) and 34 days (L2), the following products were obtained: diced meats (DM), marrowbones (MB), steaks (S) and minced meat (MM). After processing, samples were packaged in MAP, using polystyrene two mm thick rigid trays that, after flushing with the selected gas mixture $\left(66 \% \mathrm{O}_{2}, 25 \% \mathrm{CO}_{2}\right.$ and $\left.9 \% \mathrm{~N}_{2}\right)$, were closed by heat-sealing in a high barrier film (oxygen transmission rate of 1.8 $\mathrm{cm}^{3} / \mathrm{m}^{2} / 24 \mathrm{~h} / \mathrm{bar}$ ). All the products were divided into two batches and stored in the dark at $+2 \pm 2^{\circ} \mathrm{C}$ (ideal retail condition storage) and $+8 \pm 2{ }^{\circ} \mathrm{C}$ (simulating a temperature abuse condition). During storage period, the tempera- 
ture was monitored by datalogger (Tynitag Plus).

Sampling and analysis were conducted at the following intervals: zero (T0), seven (T7) and 14 (T14) days. Overall, 40 samples were analysed, 10 for each kind of product. Prior to lab analysis, the following organoleptic characteristics of the packaged samples were evaluated: i) package collapse; ii) drip loss; iii) meat and fat colour. The gas composition of headspace in packages was measured with a digital $\mathrm{O}_{2}$ and $\mathrm{CO}_{2}$ analyser, Combi checkmate 9900 (PBI Dansensor; Dansensor, Ringsted, Denmark), and expressed as percentage. The remaining gas was calculated as $\mathrm{N}_{2}$.

Samples were analysed for colony count at $30^{\circ} \mathrm{C}$, Enterobacteriaceae, Salmonella spp., E. coli, VTEC, L.monocytogenes as previously described; Lactobacillus spp. (LAB) by using Man Rogosa Sharpe medium Agar (pH 5.6) (Oxoid, Milan, Italy), at $30^{\circ} \mathrm{C}$ for five days; Pseudomonas spp. on Pseudomonas agar base with cetrimide, fucidine and cephaloridine (CFC) (Oxoid), at $25^{\circ} \mathrm{C}$ for $48 \mathrm{~h}$; Salmonella spp., L.monocytogenes and E.coli VTEC, as previously described.

Moreover, an analysis of variance (ANOVA) using the general linear model (GLM) procedure was performed for all considered variables, and when F-values were significant at the $\mathrm{P}<0.05$ level, mean differences were separated by the least significant differences (LSD).

\section{Results}

\section{Measurements at slaughterhouse and at processing plant}

Carcass pH and temperature showed a regular dynamic. The $\mathrm{pH}$ values (minimum and maximum) ranged from 6.1 to 6.8 , and from 5.5 to 5.7 , respectively one and 24 hours after slaughtering.

The investigated parameters of the carcasses showed low mean values. The mean counts were $3.51 \pm 0.46$ and $1.36 \pm 1.35 \mathrm{Log} \mathrm{CFU} / \mathrm{g}$ for colony count at $30^{\circ} \mathrm{C}$ and Enterobacteriaceae respectively, in compliance with the criteria fixed by EC Reg. 2073/2005 (European Commission, 2005). VTEC, Salmonella spp. and $L$. monocytogenes were not detected in any of the samples.

\section{Shelf-life studies}

During the storage period of the samples at $+2^{\circ} \mathrm{C}$, temperatures ranging between 0 and $+4.7^{\circ} \mathrm{C}$ were registered, while for those stored at $+8^{\circ} \mathrm{C}$, the maximum recorded value was $+9^{\circ} \mathrm{C}$.

\section{Organoleptic characteristics of the samples}

Incomplete package collapse was detected at seven days of storage in a MB sample stored at

Table 1. Mean counts (log CFU/g) of total viable count, Enterobacteriaceae, lactid acid bacteria and Pseudomonas of Halal beef samples stored under modified atmosphere.

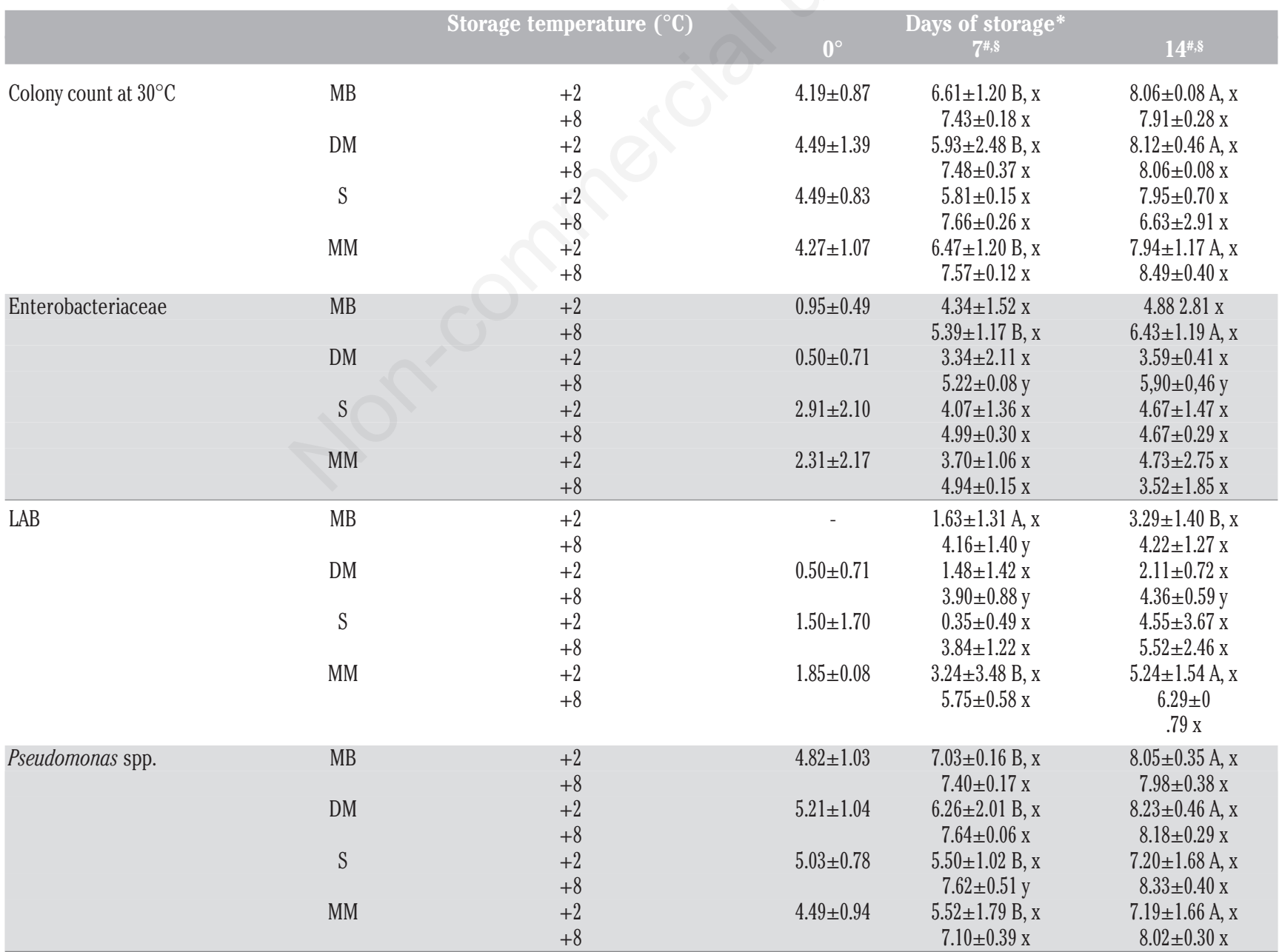

MB, marrowbones; DM, diced meats; S, steaks; MM , minced meats; LAB, lactic acid bacteria. *All values are expressed as mean \pm standard deviation; ${ }^{\circ}$ samples at day 0 were stored at $+2^{\circ} \mathrm{C} ;{ }^{*} \mathrm{~A}, \mathrm{~B}, \mathrm{C}$ - means within rows with different capital case letters are significantly different $(\mathrm{P}<0.01) ;{ }^{8} \mathrm{X}, \mathrm{y}$ - means within columns with different capital case letters are significantly different $(\mathrm{P}<0.01 ; \mathrm{P}<0.05)$. 
$+2^{\circ} \mathrm{C}$ and in a $\mathrm{DM}$ stored at $+8^{\circ} \mathrm{C}$. The same characteristic was recorded at14 days of storage in $87.5 \%$ of the samples stored at $+8^{\circ} \mathrm{C}$. Drip loss was detected starting from the $7^{\text {th }}$ day, particularly in samples stored at $+8^{\circ} \mathrm{C}$. Meat color showed a progressive darkening during the storage period, particularly in samples stored at $+8^{\circ} \mathrm{C}$.

\section{Headspace composition}

The gas composition of each package changed significantly during the storage period, related to the temperature of storage and the growth of certain microbial groups (LAB and Pseudomonas spp.). Oxygen concentration decreased with a different trend in the various products. At the end of storage at $+2^{\circ} \mathrm{C}, \mathrm{O}_{2}$ content decreased to values approaching $10 \%$ for MB, DM and S samples, and 34\% for MM samples. Such decrease was more evident in the samples stored at $+8^{\circ} \mathrm{C}$ with a $\mathrm{O}_{2}$ concentration of 0.1-0.6\%, except for $\mathrm{S}$ samples in which a final value of $11.0 \%$ was recorded. Carbon dioxide concentration showed a different trend with the temperature of storage. In the samples stored at $+2^{\circ} \mathrm{C}$, such trend was irregular for all the kind of products, and the final $\mathrm{CO}_{2}$ values were comprised between 15.0 and $18.0 \%$. On the other hand, an increase was observed, at the end of storage, in samples stored at $+8^{\circ} \mathrm{C}$ that showed final values ranged from 81 to $89 \%$.

\section{Microbiological analyses}

The results of the viable counts of the targeted microbial groups in the different kind of samples packaged under MAP (Log CFU/g; mean \pm sd) are showed in Table 1.

\section{Marrowbones}

Colony count at $30^{\circ} \mathrm{C}$, Pseudomonas spp. and $\mathrm{LAB}$ mean counts of samples stored at $+2^{\circ} \mathrm{C}$ increased gradually $(\mathrm{P}<0.01)$ with the storage time. At seven days of storage Enterobacteriaceae and Pseudomonas spp. showed levels of $10^{4}$ and $10^{7} \mathrm{CFU} / \mathrm{g}$ respectively, irrespective of the storage temperature and Pseudomonas spp. was the dominant species at the end of storage. LAB presented a less significant increase respect to Pseudomonas spp., showing mean counts of $10^{3} \mathrm{CFU} / \mathrm{g}$ at the $14^{\text {th }}$ day.

\section{Diced meat}

Mean levels of the targeted microbial groups were lower than in MB samples, but in the samples stored at $+8^{\circ} \mathrm{C}$, Enterobacteriaceae counts were $>10^{5} \mathrm{CFU} / \mathrm{g}$. Colony count at $30^{\circ} \mathrm{C}$ $(\mathrm{P}<0.01)$ and Pseudomonas spp. counts increased significantly during storage irrespective of the temperature.

\section{Steaks}

Microbial profile was similar to DM samples, but in those stored at $+2^{\circ} \mathrm{C}$ mean values were lower for all the targeted microbial groups, par-

ticularly for Pseudomonas spp.

\section{Minced meat}

Colony count at $30^{\circ} \mathrm{C} \quad(\mathrm{P}<0.01)$, LAB $(\mathrm{P}<0.05)$ and Pseudomonas spp. $(\mathrm{P}<0.05)$ showed a significant increase with storage time. LAB attained final counts higher than 5 $\log \mathrm{CFU} / \mathrm{g}$ at the end of storage, at both temperatures. L. monocytogenes, E.coli and VTEC were not detected in any of the samples. Salmonella spp. (S. Muenchen) was detected in a MB sample at zero day of storage.

\section{Discussion}

Results of our study seem to be influenced by the variety of the investigated products. Aerobic Gram-negative bacteria are responsible for spoilage and are the predominant flora in fresh meat and meat preparations with $60 \%$ $\mathrm{O}_{2}$ MAP (McMillin, 2008; Esmer et al., 2011). Some authors report that microbial spoilage of food occurs when colony count at $30^{\circ} \mathrm{C}$ and/or Enterobacteriaceae counts reach $10^{7} \mathrm{CFU} / \mathrm{g}$. In the present work, colony count at $30^{\circ} \mathrm{C}$ levels reached $10^{7} \mathrm{CFU} / \mathrm{g}$ at 7 days at $+8^{\circ} \mathrm{C}$ and at 14 days at $+2^{\circ} \mathrm{C}$. This can be explained with the high levels of Pseudomonas spp., that was the dominant population at both temperatures at the end of the storage time. Moreover, colony count at $30^{\circ} \mathrm{C}$ and Pseudomonas spp. mean counts were higher than those detected in the same kind of products packaged under vacuum. The gas composition of each package changed significantly during storage period. It is known that gaseous environment within a modified atmosphere pack is not static. It may be the result of microbial growth, the permeability of packaging material, and respiration of the product or the gas absorption by the food (McMillin, 2008). It is an expected result for $\mathrm{CO}_{2}$ concentration to decrease for the absorption by the water and lipid portions of meat until saturation or equilibration is reached. However, in our work, such decrease could be observed only for samples stored at $+2^{\circ} \mathrm{C}$, presumably due to the microbial growth. During the storage the majority of microorganisms present in meat uses the available oxygen in the headspace, while others such as Brochothrix thermosphacta and LAB, produce carbon dioxide (Esmer et al., 2011).

\section{Conclusions}

In order to extend the shelf-life it could be considered to use higher $\mathrm{CO}_{2}$ concentration, with the aim to prevent the growth of Gramnegative bacteria which are generally more sensitive to this gas respect to Gram-positive.

\section{References}

Bonne K, Verbeke W, 2008. Muslim consumer trust in halal meat status and control in Belgium. Meat Sci 79:113-23.

Esmer OK, Irkin R, Degirmencioglu N, Degirmencioglu A, 2011. The effects of modified atmosphere gas composition on microbiological criteria, color and oxidation values of minced beef meat. Meat Sci 88:221-6.

European Commission, 2005. Commission Regulation of 15 November 2005 on microbiological criteria for foodstuffs, 2073/2005/CE. In: Official Journal, L 338, 27/12/2007.

European Community, 2008. Technical guidance document on shelf-life studies for Listeria monocytogenes in ready-to-eat foods 2008. European Community ed. Available from: http://ec.europa.eu/food/food/biosafety/salmonella/docs/shelflife_listeria_monocytogenes_en.pdf

ISO, 1996. Microbiology of food and animal feeding stuffs. Horizontal method for the detection and enumeration of Listeria monocytogenes. Part 1: Detection method. IS0 Norm 11290-1:1996. International Standardization Organization ed., Geneva, Switzerland.

ISO, 1998. Microbiology of food and animal feeding stuffs. Horizontal method for the detection and enumeration of Listeria monocytogenes. Part 2: Enumeration method. ISO Norm 11290-2:1998. International Standardization Organization ed., Geneva, Switzerland.

ISO, 2001. Microbiology of food and animal feeding stuffs. Horizontal method for the enumeration of beta-glucuronidase-positive Escherichia coli. Part 2: Colony-count technique at 44 degrees $\mathrm{C}$ using 5-bromo4-chloro-3-indolyl beta-D-glucuronide. ISO Norm 16649:2001. International Standardization Organization ed., Geneva, Switzerland.

ISO, 2002. Microbiology of food and animal feeding stuffs. Horizontal method for the detection of Salmonella spp. ISO Norm 6579:2002. International Standardization Organization ed., Geneva, Switzerland.

Mazzette R, Mureddu A, Busia G, Mazza R, Lamon S, Meloni D, 2012. Prevalence of verocytotoxin-producing E. coli (VTEC) in sheep meat at slaughterhouse. In: Pugliese A, Gaiti A, Boiti C, eds. Veterinary science: current aspects in biology, animal pathology, clinic and food hygiene. Springer ed., The Netherlands, pp 161-165. McMillin KW, 2008. Where is MAP going? A review and future potential of modified 
atmosphere packaging for meat. Meat Sci 80:43-65.

Nakyinsige K, Bin Che Man Y, Qurni Sazili A, 2012. Halal authenticity issues in meat and meat products. Meat Sci 91:207-14.

Simoons FJ, 1994. Eat not this flesh. Food avoidances from prehistory to the present. The University of Wisconsin Press,
Madison, WI, USA.

UNI, 2004a. UNI ISO 21528-2:2004 Norm.

[Microbiologia di alimenti e mangimi per animali - Metodi orizzontali per la ricerca e la conta di Enterobatteriacee - Parte 2: Metodo della conta delle colonie]. [Regulation in Italian]. Italian Unification Institute ed., Milan, Italy.
UNI, 2004b. UNI EN ISO 4833:2004 Norm.

[Microbiologia di alimenti e mangimi per animali - Metodo orizzontale per la conta di microrganismi - Tecnica della conta delle colonie a $30^{\circ} \mathrm{C}$ ]. [Regulation in Italian]. Italian Unification Institute ed., Milan, Italy. 